\title{
Railway Connection between the Countries of Corridor VIII and the Oportunities of Trade Development
}

\author{
Fabjola Bramo, PhD candidate \\ Ministry of Interior of the Republic of Albania, Tirana, Albania \\ Email: fabjolabramo@yahoo.com \\ Mobile: +355694109159
}

\section{Doi:10.5901/mjss.2013.v4n11p418}

\section{Abstract}

During the recent decades the world has been faced the globalization more than ever. Countries have taken the form of a huge global village. Need to trade have increased efforts to meet customer needs. Trade between countries has become necessary to improve the infrastructure. Railway is one of the most economical means of transportation. To promote economic development, it is anticipated the construction of Corridor VIII connecting the Adriatic Sea to the Black Sea. This corridor is extended from Bari and Brindizi to Burgas and Varnas. Albania ëill serve as a connection point between west and East Europe. In this paper we will discuss the positive effects of the construction of the railway Corridor VIII in the development of trade between Italy, Albania, Macedonia, Bulgaria, Greece and Turkey. It will also identify opportunities for the development of these countries and will be treated as a barrier that may inhibit economic development.

Keywords: Corridor 8, railway development, economic benefits, railway infrastructure, trade development

\section{Introduction}

Albania and some of the other Balkan countries have signed the Stabilization and Association Agreement with the EU. In this context, Albania must respect the pillar for democracy and human rights, the issue of security and an important pillar where this agreement is based which is the economic development and reconstruction. In the context of this column, it must be said that Albania has signed several important agreements with the EU and Balkan countries to market liberalization. In this way it will be possible to promote free trade among countries and ensure future prosperity.

In this work, we will not stop to analyze the agreements in terms of benefits for each of them. We shall stop only on issues related to favoritism that makes development of railway to the trade relations in the context of the signing of these agreements. Countries that are included in Corridor VIII railway are Albania, Macedonia, Bulgaria, Italy and Turkey, which will link voluntarily to this corridor. These countries have trade relations between them related by the Free trade agreement. Albania currently has the lowest rate of imports in the region. In recent years our country has signed different regional agreements for the liberalization of markets. Most important among them are: CEFTA and the free trade agreement with the EU. Based on these agreements Albania has the right to export goods without tariffs or low tariffs towards the EU. in the course of these agreements, Albania is an important partner in Eu exports to about $77 \%$ of products and $62 \%$ of imports.

\subsection{Methods}

This qualitative study employs the characteristics of railway system in Albania. The purpose is to find out how railway in Albania can provide an economic development. The case study was written based on literature, official data from Albanian railways, and round tables with experts of the field, economy, sociology, business etc. All these sources and discussions gave us information to prepare this paper. We must point out that the lack of the official information about the railway number of passengers and volume of good limited us on doing this. There is no data and statistics about railway transport volumes in EUROSTAT and INSTAT.

\subsection{Research objectives}

The hypothesis of this paper is: 
How important is the development of railway network in Albania and which are the economic and social benefits? The objectives of this paper are:

- Obtain an extended view of railways in Albania

- Identifying the importance of this transport

- Exploring the causes of the barriers and opportunities for development of railways in Albania

\section{General overview}

Request for use of rail for passengers as well as for businesses has been growing more and more in recent years. In this situation, when the transport is considered quite economical and advantageous for the population, the most difficult issue is the investment required in this area. Railway Transport category is mainly used for cargo and passenger transport (Di Pietrantonio \& Pelkmans 2004: Deloitte 2011). Transport is considered very favorable and carries some social and economic value compared to other types of transport. Literature suggests that among the advantages of rail, we can highlight: urban distribution, producing fewer carbon, less accidents, removal of social barriers as a result of the urbanization of areas, increasing the value of real estate, the highest level security etc. (Deloitte 2011)

Albania's geographical position is a strategic country in the Balkans. It serves as a bridge to the West for trade relations between the countries. Despite the geographical position and favorable conditions for investments it provides, Albania has a transport network that leaves much to be desired. Developed railway infrastructure will give another impact to the economic development in the country and will contribute positively in trade relations.

Railways directly influenced the development of cities and economies around the world. As one of the most powerful tools that capitalism used to his arrival, railways gave contribution in the development of various industries, in the early mines factories and plants and then transport of the passengers. In our country the railways were built relatively late compared to other countries of the world. In this chapter we will present a historical overview of the Albanian railway.

Globalization of the economy and liberalization of markets has resulted in an urgent need of transport of products from one place to another. In our days, the products are transported not only in close geographical locations but also internationally. Expansion of the European Union member states and other new or aspiring candidates was accompanied by the growth of markets and therefore, goods and passengers traveling from one place to another.

In the Central Europe rates of use of transport are the same excluding Bosnia and Herzegovina and Slovenia. On the other hand in Western Europe the use of trains is high. Increased investment in the rail network continuous improvements liberalization of transport markets encourages further the development of railway transport than road transport.

\section{Physical condition of rails in Albania}

Railways in the country dates back to 1947 when first was constructed the axis linking Durres Peqin the intention of using trains for passengers goods and trains on the same line. The train crossing was done in strict schedules and signs that made it possible to avoid accident because there was only one railway track crossing. By 1986 Albania had built all axes that currently have nowdays, including railway line Hani Hoti which serves to connecting Montenegro for the transport of goods. It was a completely industrial railway line, because at that time Albania was isolated and the citizens were not allowed to to move abroad. On the eastern side of the country, near the border with Macedonia, the railway reaches up to Red Stone, near Pogradec. In communist government projects envisaged the establishment of a railroad bridge connecting this side of the border was not foreseen.

The length of the railway is 447 kilometers, of which 425 are in use, 23 kilometers are outside function. Currently 370 miles should be replaced as they are enough amortized. The average speed of the passenger trains is about $40 \mathrm{~km} /$ $\mathrm{h}$ while of the the goods is $25 \mathrm{~km} / \mathrm{h}$. Another problem that is added to the amortized lines and old trains is the fact that in total there are 160 illegal crossovers which prevent the normal flow of trains, and may cause delays ansd stops in traffic. Also these crossovers are the main source of accidents occurring in Albania with trains. Albanian Railways has currently only 57 locomotives, of which only 19 are in use. Wagons are 537, but less than half of them have the capacity to use, 231, while passenger wagons are 44.

Tirana-Durres line is one of the main railway lines in the country, with a length of 37 kilometers with a total of five stations. The speed of the trains is about $60 \mathrm{~km} / \mathrm{h}$ after the last reconstruction was performed. Line-Vore- Shkoder- Hani i Hotit - is the longer than $120 \mathrm{~km}$ with 10 stations. This line is the line completely industrial and trains have a speed of 25 
$\mathrm{km} / \mathrm{h}$. Durres, Elbasan line is 75 kilometers long, with 9 stations and trains with an average speed of $40 \mathrm{~km} / \mathrm{h}$. Another important line is Rrogozhinë-Vlora with a length of $85 \mathrm{~km}$, with 9 stations and a speed of $40 \mathrm{~km} / \mathrm{h}$. Last but not least is the -Elbasan, Pogradec with a length of $75 \mathrm{~km}$, with 8 stations and a speed of $40 \mathrm{~lm} / \mathrm{h}$. There are 5 branches in the railway network, branching to the port Durres, branching Budull-cement factory Fushe Kruja, branching Elbasan- cement factory, branching Ballesh Fier, Elbasan Kürüm branch.

Rail network standards would create more incentives for the development of trade, but also the free movement of the citizens. Port of Durres and Vlora and Shëngjin are a great opportunity for the development of trade with Italy. On the other hand, our country borders with Macedonia to the east and northeast. Pan-European Corridor VIII passes in Macedonia. The nearest railway lines in Macedonia, is Struga while in our country is the Red Stone. It is sufficient is just 2.8 miles to connect two respective railways in Pogradec Lin village and a sum of around 7 million euros. Albania's involvement in this Corridor would give a positive impact both on economic and social aspect in that country.

\section{Analysis results}

Rail corridors make it possible to development of the countries and regions they that link and passthrough them. If refer to international corridor between Rotterdam and the Harbour of Costanca in Romania the literature suggests that it has brought interoperability to the area and generate better opportunities for competition. International undertakings generate multiple sources of the systems plan and might be a key investment target. Distribution of the goods in different states makes more efficient the infrastructure makes it more liveliness of the frrit rail market transparency. But in this regard be taken into consideration that the role of human resources is critical related to the value of knowledge for implementation of transport services with low cost (Simola \& Szekely 2009).

Relationship between countries of Corridor 8 has numerous benefits not only for them but for the whole region in terms of economic and social development. Construction of Corridor VIII rail carries political and economic values for several different reasons. At first this corridor is part of the Pan European Corridors network aiming to connect all countries and stimulate economic development of the trade and passthrough them. On the other hand is a good opportunity to establish a bridge between West and East to the fact that it aims to connect a European country such as Italy in the Adriatic Sea with a country like Bulgaria in in the Black Sea and then to other countries of origin. Countries of east all come from totalitarian regimes and have developed a system of free trade only these last two decades. Their economic and trade level is lower in comparison with Italy which has a consolidated capitalist economy. In this context, economic value are added even those geopoliticalwhen it is known Balkans and especially Albania is an integral part in the Eastern Europe.

Second, from an economic perspective the construction of a railway infrastructure with lower cost and reduce travel time adding comfort and safety conditions enables the development of free markets between the countries. Balkan region is in within the EU integration (Bulgaria is is a member with rights full and Greece) while Albania Macedonia and Turkey aspire to join the great European family.

Despite its convenient geographic position geographic favors made by the state to encourage foreign businesses to invest in Albania Albania's trade relations with the EU in 2012 left much to be desired. For countries with which the EU imports Albania still ranks last in the 60 -with $0.1 \%$ or 2,376 million euros. In the list of the trade partners Albania is ranked 68th with $01 \%$ of the total, or 3,489 million euros.

\subsection{Benefits of Corridor VIII}

To speak of the benefits generated by the connection of the railway infrastructure means primarily economic improvement. Countries related with this Corridor would be given the opportunity to have facilities and a trade with all countries of the Europe. In a way, there will be a drop of virtual borders that will give push to the development of trade. The construction of the Corridor VIII aims to shorten the distance Durres-Sofia to $500 \mathrm{~km}$ will, was of give equal opportunity of developing countries and regions affected by this corridor.

Furthermore we will present a list of expectations this corridor:

Reducing the distance from Durresi to the Bulgarian capital, Sofia. The distance to be provided by railway is expected to compete the distance that actually offers the road transport. The estimates provided a distance in about 5 hours. With the construction of this corridor Macedonia is expected to be only 200 kilometers away from the Black Sea and about 150 kilometers from Istanbul. If refer to the corridor 8survey, we learn that the average speed of trains that will travel to the Corridor will be over the whole length equal to $100 \mathrm{~km} / \mathrm{h}$. In this way, the distance from Skopje to Istanbul 
will be around 1 hour and a half. Based on distances from Macedonia we can calculate the distance from Albania. Less than two hours journey from Macedonia to Durres.

In the space of 8 rail corridor is expected to circulate 10 cargo trains per day. Under this project the weight will be kept by these trains is 400 trucks. In the space of 8 rail corridor is expected to circulate 10 cargo trains per day. Under this project the weight will be kept by these trains are 400 trucks.

Meanwhile, the railway line to be built from Kristollopogji in Greece that will link border crossing with Kapshtica and then with Lin, will provide good opportunities of to the development of transport of the passengers and goods. Not only Albania will have access of the rail link with Greece but also Macedonia. Thessaloniki as an important tourist destination of Greece would be more susceptible to Macedonian citizens.

The last benefit but not less important is the fact that the improvement of rail transport for goods and passengers especially will make possible large facilitates for Macedonian citizens. They will thus have closer Coast and mountain destinations in Albania Bulgaria Greece and Turkey, but will give them the opportunity to explore and areas within Macedonia.

\begin{tabular}{|c|c|}
\hline Strong Points & Weak Points \\
\hline 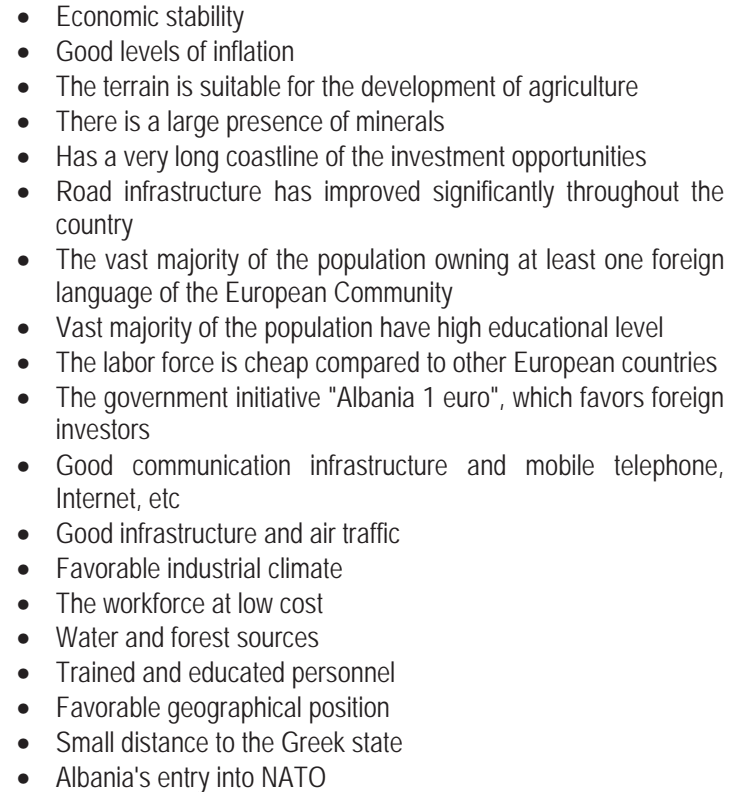 & $\begin{array}{l}\text { - Markets are not fully developed } \\
\text { - Problems of land ownership, still unresolved } \\
\text { - Problems on the privatization of former state } \\
\text { enterprises } \\
\text { - The migration rate is high } \\
\text { - Difficult conditions for bank credits } \\
\text { - High borrowing interest }\end{array}$ \\
\hline Possibilities & Risks \\
\hline $\begin{array}{l}\text { - Supportive government policies are quite favorable for foreign } \\
\text { investment } \\
\text { - Registration procedures for foreign businesses are shortened } \\
\text { - The Albanian membership in NATO } \\
\text { - Signature of MSA (stabilization agreement and association) } \\
\text { - The visa liberalization with the EU } \\
\text { - Albania is no longer considered a transition state } \\
\text { - Numerous opportunities for improving industrial infrastructure } \\
\text { - } \text { and initiatives to attract potential industries } \\
\text { that posssess Albania (food industry, mining, construction, } \\
\text { - } \text { farming, fishing, etc.) } \\
\text { - The European liberalization markets } \\
\text { - } \text { Achieving set standards for global trade }\end{array}$ & $\begin{array}{l}\text { - Replace investments in Albania with } \\
\text { Montenegro, Macedonia, Kosovo, } \\
\text { - } \text { etc.Konkurrenca e pandershme } \\
\text { - } \text { Air pollution from smog } \\
\text { - Illegal construction } \\
\text { - The political crisis between majority and } \\
\text { - opposition forces } \\
\text { - The global economic crisis } \\
\text { - Illegal unfair competition } \\
\text { - } \text { imported from the East prices of indigenous or } \\
\text { - The lure of a potential competitor from the west } \\
\text { - Monopolization of the industry which aims to } \\
\text { invest }\end{array}$ \\
\hline
\end{tabular}

SWOT analyses for Albanian economy, trade and development 


\section{Conclusions}

One of the aims of this study was to bring attention to the value of the construction of Corridor VIII in establishing economic relations between the countries affected by this transport. It must be admitted that until now, this project has not been any major development, at least in the case of Albania. Conditions continue to remain the same, although Albania expects to gain candidate status conditional on European Union. The first prospective comparison with the other countries, Albania in this regard is left behind. Railway Law was approved late and did not comply with the regulations rules under EU directives. Railway situation remains so backward in terms of both cargo transportation and passenger in it. Some of the countries that are members of CEFTA in 2006, but relations have not been successful for the fact that road transport costs are higher than those of railway. On the other side, it is worth noting the fact that Albania has important trade partner Italy and \Macedonia. The works on the outcome of this corridor will further develop these relations.

The developement of this transport, which accounted to offer lower fees than other means, could promote the development of trade between countries in the region and beyond. Besides commercial exchanges between countries involved in Corridor VIII, Albania has geographic favor to serve as a key for transport from the Adriatic Sea to the Black Sea. Upon rational Albanian government and interest groups for starting work on a much faster time, will promote and develop trade significantly in these countries. In the future is thought to be succeeding railways transport, as considered with good reputation in environmental issues. There are many studies in literature as western and Eastern Europe to treat railroad as an attractive market for investment. The future of railway transport is considered golden. Railways transport is considered as an effective and ecological transport, factors these which can be used in their marketing. Yet are issues related to high technology, their accuracy, providing good service and affordable tariffs that serve as attractive in the development of railways. To attract new investors is necessary to assist new arrivals with bureaucracy. In this way the selection of new operators will provide potential competitors (Simola \& Szekely 2009).

\section{References}

Albanian Transport Policy and Core Network (2007) Ministry of Public Works and Transportation ALBINVEST (2008) Albanian Infrastructure Today

Berger. L, S.A (2005) Albania National Transport Plan-Phase 2 Study Draft Final Report, 29-31, 47, 50

Business Plan HSH, Development of service 2010-2016

Business plan of HSH in Albania (2007) The infrastructure

Deloitte Acces Economics (2011) The true value of railway. The Australiasian Railway Association

EBRD (2006), Albania Strategy Overview

European Railway Deregulation (2009) Essays on efficiency and productivity of European railways

Gómez-Ibáñez.J.A (2004). Railroad Reform:An Overview of the Options. Paper to be presented at the Conference on Railway Reform Rafael del Pino Foundation Madrid September 18-19, 2004

Hilmola.O-P, Szekely.B (2006) Deregulation of Railroads and Future Development Scenarios in Europe-Literature Analyses of Privatization Process taken place in US, UK and Sweden, Finland

http://www.aida.gov.al/

http://www.ebrd.com/pages/project/eia/42921.pdf

http://www.iadb.org/intal/intalcdi/PE/2009/02948.pdf

International Transport Forum (2008) Charges for the use of Rail Infrastructure

Kehoe. O (2003) Economics of Truck and Rail Freight Transportation/ A look at public and external costs and the truck-rail model split

Laisi, M (2009), Market Entry Strategies and confronted barriers on Liberalized Railway Freight Markets in Sweden and Poland, pages $15-18$

Laisi, M (2010), Business Environment and Future Opportunities in Russian Railway Freight Market

Laisi. M (2009) Market Entry Strategies and Confronted Barriers on Liberalized Railway Freight Markets in Sweden and Poland, pages $20,24,26,28,39,40-43,52-55$

Laisi.M (2009), Market Entry Strategies and Confronted Barriers on Liberalized railway Freight Market in Sweden and Poland, Finland

Laisi.M (2010) Business Environment and Future Opportunities in Russian railway Freight Market, Finland

Makitalo. M (2007) Market Entry and the Change In Rail Transport Market When Domestic Freight Transport Opens to Competition in Finland. Finland

Ministry of Transport and Public Works 2007-2013 (2007) Sectorial Strategy of Transport, pages 15, 25, 38, 45

World Bank (2008) Western Balkans Integration and EU

www.ubt.edu.al/rssb/ajas2012papers 